\title{
Cultural Resistance in Occupied Palestine and the Use of Creative International Solidarity through Song ${ }^{1}$
}

\author{
Eurig Scandrett ${ }^{2}$, Mahmoud Soliman, Penny Stone
}

\section{Background}

The Zionist settler-colonisation of Palestine since the end of the nineteenth century, has been met by Palestinian popular resistance (Qumsiyeh 2010; Darweish and Rigby 2015). This unarmed, civilian resistance has taken many forms, including the use of Palestinian culture, arts and music (MacDonald 2013). Palestinian resistance has also drawn on international expressions of solidarity, especially since the 2005 call for Boycott, Divestment and Sanctions against Israel (BDS Movement nd; Barghouti 2011). This paper explores an area of practice of international solidarity, building on Palestinian popular resistance, and based on the use of protest song by a Scottish community choir. Although drawing on aspects of original empirical research (Soliman 2019), this is not primarily a research paper but rather a critical reflection on the use of song in popular resistance and solidarity action, as an example of nonviolent solidarity praxis by three activists who are participants in the movement. Its particular focus is San Ghanny, a community choir based in Edinburgh established for the purposes of solidarity with the Palestinian popular resistance.

San Ghanny (Arabic for 'We Shall Sing') is a community choir established in Edinburgh in 2011 for the purpose of expressing solidarity through song with the Palestinian people. In addition to the professional musician Penny Stone, the choir comprises twelve amateur singers (originally ten), all with sympathies towards Palestinian human rights but with varying levels of experience of solidarity activities and nonviolent protest. All the choir members are based in and around Edinburgh, and none is Palestinian or native Arabic speaking. The development of the choir as an expression of solidarity was based on connections and dialogues with Palestinian activists in Edinburgh and the West Bank.

\footnotetext{
${ }^{1}$ This paper is based on a presentation to the international conference Art and Activism, Resilience Techniques in Times of Crisis, December 2017, Leiden, The Netherlands.

${ }^{2}$ Corresponding author: Queen Margaret University, Edinburgh. escandrett@qmu.ac.uk
} 
The article will first consider the context in which music and other cultural forms have been an intrinsic part of the popular resistance to Zionist and British colonisation, before reflecting on the significance of music to social movements in general. Turning to the Scottish context, the article will explore how Scotland's musical traditions have responded to the nation's contradictory internationalism. The main argument of the article will reflect on the experience of the community choir San Ghanny and its music. Through such reflections, the work of San Ghanny is positioned within the community of political singers which contribute a structure of feeling across international movements for justice, and a community of struggle in solidarity with the Palestinian popular resistance.

The authors are all activists. Soliman has played a leading role in the popular resistance movement in the West Bank as an organiser and researcher. Stone is a professional community musician based in Edinburgh, Scotland, formerly a human rights defender in the West Bank and leader of the San Ghanny. Scandrett is an academic public sociologist active in the Scottish Palestine solidarity movement and a member of San Ghanny (al-Shalalfeh, Napier and Scandrett 2018; al-Butmeh et al. 2019). This paper is based partly on Soliman's personal experiences since the first intifada (uprising) and involvement in the nonviolent movement in Palestine, in addition to research conducted by semi-structured interviews and focus groups with Palestinian activists and political leaders (Soliman 2019). In addition it draws on the experiences of Stone and Scandrett of solidarity work both in Palestine and in Scotland as part of the international BDS movement.

\section{Music in Palestinian Popular Resistance}

Nonviolent responses to occupation have made progress in stopping or delaying the Zionist/Israeli policies in Palestine, at times when diplomacy and other tactics have not managed to end the occupation. This response came from the daily lives of Palestinians, through their resilience and culture of resistance. Art, particularly protests songs, have played an important role in mobilising people to be able to counter the policies of the Israeli occupation (McDonald 2013).

Protest songs have always played a crucial role in mobilising people and the first intifada (uprising) witnessed many songs (McDonald 2013). The first intifada, from 1987 to 1993, was a 
nonviolent uprising of Palestinians in the Palestinian territories that had been occupied by Israel since 1967 (West Bank and Gaza Strip), which was met with violent repression of unarmed protestors by the Israeli military. Music, poetry, song and dance were a predominant means of social and political mobilisation which, along with leaflets and graffiti, generated popular sentiment, shaped national and political identities and affiliations, and provided performative spaces for subverting Israeli actions. Performative media provided an essential integrating tool for the masses walking the streets in public demonstrations, allowing for new cultural and political identities to emerge. Collective singing and dancing opened up spaces for the integration of new communities and ideologies, what Duncan Hall refers to as 'culture of struggle' (Hall 2001: 93). There was a crucial role for revolutionary songs in influencing the psychological feeling of Palestinians, strengthening them against the injustice and oppression by the Israeli occupation forces and helping to mobilise them towards rejecting those procedures and confronting them.

Israel knew from the beginning the key role of revolutionary songs in mobilising people. Israel collectively punished Palestinians for singing these songs or distributing them or even producing them inside occupied Palestine. It closed all theatres and places where people could perform. McDonald (2013) noted that Khoury was a Palestinian singer who was jailed for 10 years, accused of incitement, for producing songs during the first intifada. One of the activists from the intifada living in the village of Al_Ma'sara said "I was jailed for six months in the Israeli jails for being involved in selling cassettes for the protest songs".

The Oslo Accords, which ended the first intifada, heralded new forms of Israeli repression, including, from 2002, the construction of the segregation wall (also known as Apartheid wall because its purpose is to enforce racial segregation between Palestinian and Jewish communities). Since 2002, the Popular Resistance Committees have organised demonstrations against the segregation wall and the expansion of Israeli colonies within occupied West Bank. The popular committees always connect the demonstrations with local and international themes, in order to mobilise more local people to participate. In Al-Ma'sara village in one of the demonstrations on the $14^{\text {th }}$ May 2012 on the 62 anniversary of Nakba (the catastrophe of Palestinian expulsion by Zionist militia of 1948), it was decided to have a folklore day to return to the lifestyle of the Palestinians before the Nakba, to resist through art. Reem Bana, a famous 
Palestinian singer, was invited to sing revolutionary songs for the people, and the women cooked traditional food and bread. The national songs that Reem sang were enough to mobilise the people from the village, all of them wanted to come and listen to the Palestinian music and the national songs. The difference between performing the songs in a theatre, and performance in a demonstration, is in the feeling when the national songs and music are turned into action on the spot, and a source of challenge to the occupation. As one of the participants said "when I heard the music and the songs with the 'speakers in the village while I was in my room I jumped immediately, I felt the power, my body was mesmerised and I was unable not to participate in the demonstration, I was able to move the mountains when I was listening to the revolutionary songs in the demos, you feel that you are able to defeat the army just by listening to the songs in front of them. When I heard the songs at that day I felt my strong identity. Listening to the songs in such context increased my determination to end the occupation".

This was not the only way to use music as a source of mobilising Palestinians: in the period 2004 -2014 Palestinian popular committees used drummers to mobilise people. In each village there is a group of drummers who participate in the demonstrations leading the protests while playing the drums. One of the youths in the village told me that "when you march in the demonstrations while the drummers are playing you feel that when you step on the ground you are able to push it, you march while your head is up, full of dignity and pride". Each active village got a sound system and DJ to lead the demonstrations.

Protesters created the protest songs in different languages; Arabic English and Hebrew:

La la lljedar (no no to the wall)

Hadoo eljedar fee Berlin wa rah enhedoo fee falastine (they demolished the wall in Berlin and we will demolish it in Palestine)

Namout wa tahya falastine (we die for the life of Palestine)

One two three four occupation no more - 5,6,7,8 Israel is occupation state.

Men elma'sara tel' elqarar eljedar lazem yinhar (from Al-Ma'sara the decision was taken the wall must fall) 
One of the pillars of the nonviolent resistance in Palestine is the joint struggle were people demonstrate together from different nationalities, religions and colours. Joint struggle enabled activists to create a common space for all the people to create a mixed culture of resistance. The first things to come out of this space were the songs in different languages. Despite the different languages each of them speak, this was a powerful tool to enable people to stand up against the occupation forces. One of the villagers told Soliman that "what more beautiful and powerful to see those people together singing in different languages, Arabic, English, Italian, French,... these songs are much stronger than the weapons in the hands of the soldiers".

One of the most powerful images of the demonstrations against the segregation wall and the colonists is when the demonstrations start marching in the villages with the loudspeakers on a van singing national and revolutionary songs, which was enough to mobilise everyone in the village "We start to march, Iyad is on a van arranged by the popular committee and he starts to chant La La lel Jidar. Al jidar lazem yenhar. The crowd picks it up and we are all chanting together. "No No to the Wall. This wall is going to fall"”.

In 2013, the popular resistance committees built Bab Al-Shams, 'gate of the sun' (named after the novel by Lebanese writer Elias Khoury), in 'E1', a space designated by Israel for expansion of their Jewish-only colonies. The most powerful moments were when a group of young people in one area started to read Palestinian poems and around a fire, a group was singing and playing durbakka hand drum: all of that increased solidarity among the people and empowered them.

"Songs are the tools to empower people and to overcome the challenges and to overcome their fears, songs is the food to gain the power to win" as one of the activists said. In popular resistance, it is important to build the capacities of activists to counter the Israeli violations, and most important is the immaterial resources such as music protest songs that motivate people. As Soliman has witnessed, when the occupation forces are approached by demonstrators with songs and music, the power of the people and the weakness of the army is noticeable, how the music undermines the physical power of the occupiers.

Songs are the tools that amplify human power. Yousif is an activist from Soliman's village: when they tried to arrest him he started singing "we die for you Palestine, all our life is nothing in front of the beauty of your eyes my Palestine". He said "I felt I am between the earth and the 
sky, it was like a spiritual moment for me that gave me the energy not to feel the four soldiers who were beating me trying to arrest me".

\section{The role of song in protest}

Art brings hope to the occupied people instead of desperation: it builds bridges between the hearts of activists despite the barriers occupiers put. Revolutionary songs are the weapons to break the silence and refuse the status quo, music is the spiritual food to give life instead of death.

Folk art builds a form of cultural resilience in which resistance is embodied, in which conviviality is integrated with militancy, which is just beneath the surface and able at any time to erupt. Song in particular helps to create a culture of struggle, mobilising what Raymond Williams (1977) calls a 'structure of feeling', a collective, embryonic and emergent alternative to the present, a 'social experience in solution' (Williams 1977: 133). In protest song, the words of a song written for one political context - in some cases not for protest purposes - are written and re-written, or translated into other languages, for the purposes of other political circumstances. Words may be written collectively, or may articulate a collective concern driven by group discussions. The relationship between the trained, specialist artist and the community of participants is democratised and moves away from the risk of reification of the creative individual artist and the passive consumer.

Eyerman and Jamison (1998) emphasise the role which political song plays in social movements, linking current struggles with those in the past and in other parts of the world, so that the structure of feeling extends beyond the immediate to the universal struggle for freedom and justice.

'Music as experienced and performed within social movements is at once subjective and objective, individual and collective in its forms and in its effects. Through its ritualised performance and through the memories it invokes, the music of social movements transcends the boundaries of the self and binds the individual to a collective consciousness. This is what we have identified as the "truth-bearing" message, or the rationality, of movement music, where individual and collective identity fuse and where past and future are reconnected to the present in a meaningful way.' (Eyerman and Jamison 1998: 163) 
It is this reconnection of the truth-bearing of history in social movement, that San Ghanny sought to develop through responding to the music of the Palestinians popular struggle, connecting with movements and diverse struggles from different parts of the world, and rooted in the contradictory Scottish traditions of internationalism.

\section{Solidarity in the context of Scottish Internationalism}

Scotland also has a strong tradition of music, dance and especially song in the languages of Gaelic, Scots and English. Moreover, across Britain there is a tradition of four part a cappella community choir singing, including socialist and 'Clarion' choirs linked to trades unions, cooperatives, working-men's social clubs and left wing political parties (MacColl 1954; Munro and MacLeod 1996; Samuel, MacColl and Cosgrove 1985). It is from this context that the protest choir San Ghanny emerged for the purposes of singing in solidarity with the Palestinian people.

Scotland has a distinctive approach to internationalism and international solidarity. Unlike its Celtic neighbour Ireland, Scotland was never colonised. Rather Scotland made several attempts to become a colonial power itself, all of which failed. Following the ultimate collapse of Darien colony in Central America in 1700, Scotland's ruling class negotiated the union with England in 1706 and participated in the British Empire. Subaltern Scots have populated settler colonies Canada, America, New Zealand etc - since the seventeenth century, through indenture, religious and political persecution and in significant numbers following the brutal evictions associated with land enclosure in the eighteenth century, known as the Highland Clearances. The Scottish working class was also disproportionately represented in the armed forces that have enforced British colonialism.

Arthur James Balfour grew out of this class-based colonial tradition in Scotland. He was the Laird (hereditary aristocratic landowner) of Whittingehame Estate, east of Edinburgh; Chief Secretary of (colonial) Ireland 1887-1891; UK Prime Minister 1902-1905 and Foreign Secretary 1916-1919, in which position he applied his colonial wile to institutionalise Zionist colonisation of Palestine through the 'Balfour Declaration'. This statement of British government support for the Zionist project became embedded in the terms of the British Mandate of Palestine of 19221948 and thus the midwife of the settler colonial state of Israel.

But Scotland's contradictory relationship to colonialism has also retained a radical tradition of international solidarity, upon which San Ghanny was able to build. As Hamish Henderson, 
Scottish intellectual, folklorist, activist and poet wrote in his most famous song, in Scots, The Freedom Come All Ye:

Roch the wind in a clear day's dawin, blaws the cloods heelster-goudie ower the bay,

But there's mair nor a roch wind blawin ower the great glen o the warld the day

The 'roch (rough) wind' of the struggle for freedom, seen from Scotland's Great Glen, is awakening throughout the world, and is exemplified in the song from the struggles within Scottish history and globally against landlordism, militarism, colonialism and class oppression. The song acknowledges the conflicted relationship which Scotland has with colonialism by conjuring a decolonised future:

Nae mair will our bonnie callants march tae war while the braggarts crusely craw,

Nor wee weans frae pitheid and clachan mourn the ships sailin doon the Broomielaw

Broken faimlies in lands we've herriet will curse Scotland the Brave nae mair nae mair

No more will the young men of industrial and rural Scotland follow barked military orders and go to war, leaving their children to mourn; no more will the children of persecuted lands curse Scotland and its songs. Songs of struggle have the potential to name the colonial reality, acknowledge culpability in a way that celebrates anti-colonial struggle and envisages a decolonised future. Writing from the perspective of the Canadian settler-colonial state Gaztambide-Fernández (2012) proposes a practice of cultural solidarity which makes possible the creativity required for decolonisation.

'Culture is the outcome of an encounter between subjects, creatively negotiating - and sometimes rearranging - the structural conditions that produce the encounter in the first place... Creative solidarity is concerned with the multiplicity of cultural practices that might evolve in such encounters, as a way of countering the versions of 'culture' and 'identity' that are imposed by the colonial project of modernity.' (Gaztambide-Fernández 2012: 57)

As an initiative of cultural solidarity, San Ghanny was formed in Scotland in 2011 for the purposes of building solidarity with Palestinian people. The movement for international solidarity has been provided with particular focus since the 2005 call from Palestinian civil 
society for a comprehensive international campaign of Boycott, Divestment and Sanctions against the Israeli state and companies which profit from the occupation (BDS) (BDS Movement 2005; Barghouti 2011). The specific demands of this nonviolent campaign are that Israel should abide by international humanitarian law by ending the occupation of Arab lands, abolishing discriminatory policies within Israel and respecting the right of return of Palestinian refugees.

Cultural industries have always been a central plank of the BDS movement, in terms of artists publicly turning down or cancelling performances in Israel, and protests and disruptive tactics wherever Israeli state sponsored artists perform (see for example Brown 2014). Scandrett, for example, participated in a protest in which a performance at the Royal Albert Hall of the Israeli Philharmonic Orchestra, during the Proms of 2011, was disrupted by a Jewish-led amateur choir singing Israel end your occupation to the well known tune of the choral section of Beethoven's Ninth symphony (BBC 2011). International artists have also been vocal in promoting BDS and participating in a range of solidarity actions in the Occupied Territory and with Palestinian diaspora. San Ghanny became a contribution the nonviolent popular resistance in Palestine and BDS in Scotland.

\section{San Ghanny and its music}

The choir was established after one of the group, who had visited the West Bank and met with some writers and photographers, started discussing the possibility of a singing exchange with Penny Stone, a community choir leader who had formerly volunteered as a human rights observer in Palestine. San Ghanny formed from a group of volunteers, learned songs and studied nonviolence practice, and visited the West Bank for two weeks in 2012 where they met popular resistance leader Mahmoud Soliman. On return to Scotland, the choir performed in many concerts and demonstrations and told stories about the visit to Palestine. The group developed a repertoire of song, illustrated narratives and dramatic performance based on experiences and the inspiring Palestinian people who are stubbornly resisting the occupation and directly confronting its military. In 2017, the choir visited the West Bank again, to participate in the Second Nablus Festival for Culture and Arts. Whilst in the West Bank, the choir supported a number of popular resistance initiatives with Soliman. The second visit led to another series of concerts and demonstrations in Scotland and the publication of a book (San Ghanny 2017). 
The songs which formed San Ghanny's repertoire were selected to support the Palestinian popular resistance and make connections with movements throughout the world and in history: an aesthetic of solidarity. It was necessary to be able to sing songs in a wide variety of contexts, from children's nurseries to protests confronting Israeli soldiers; village hall concerts in Palestine and Scotland; impromptu sessions at flash-points; on confiscated Palestinian land and in Scottish flash-mobs; at the Scottish Parliament and in West Bank refugee camps. With the exception of Stone, the songleader, all members of the choir are amateur, with varying levels of singing experience, who needed to be able to produce a cappella music, mostly in four part harmony, of adequate quality in such diverse contexts, sometimes inviting others to join in. The choir (none of whom is fluent in Arabic) needed to be able to communicate with people who spoke no English and people who spoke no Arabic - sometimes at the same time. On occasions the music was used to communicate to Hebrew-speaking, heavily armed soldiers confronting protests. Whilst the words to the songs are important, it is the music which needs to communicate. Protest songs are not merely instrumental. As Hall (2001) emphasises in his study of music in the British labour movement: "songs of struggle" were significant as musical rather than literary phenomena. The most important thing was that the activists sang - what they sang was often secondary.' (Hall 2001: 95)

Certainly for San Ghanny, the music is central. A few songs have no English words and so when performing in Scotland it is the resonance of the music which is significant. Bella Ciao is well known as an Italian partisan song of the left, sung regularly by socialist, trade union and other working class movements. Apart from the refrain in Italian, San Ghanny sing it entirely in Arabic (Ghanni Hurriya, sing freedom). Similarly, Soyilwella, described below, is sung in KiZulu and Arabic.

However, for San Ghanny, what is sung is a very important close second to the music, and the repertoire was developed with a great deal of consideration, both artistic and political, to the words as well as the music. A selection of some of the songs and the contexts in which they have been used are given here.

\section{Anti-Apartheid}

A particularly important reference point is the struggle against Apartheid in South Africa. Not only is the South African political song tradition especially rich, the anti-Apartheid struggle has a 
strong resonance both for Palestinian popular resistance and for solidarity activists. The systematic discrimination of South African Apartheid segregated the population into different racial groups and reserved the most humiliating treatment for indigenous Africans. Resistance to Apartheid was brutally and violently repressed. It is little wonder that there is mutual recognition between Palestinians and South Africans who were involved with the struggle against Apartheid. The BDS call explicitly references South Africa and the international boycott which contributed to the struggle for a multi-racial democracy which was successfully achieved - to the extent that Apartheid was dismantled - in 1994. Many of the choir members were active in South African anti-Apartheid solidarity (in 2017 the choir members' median age was 62). The Israeli occupation of Palestine has often been described as an Apartheid regime, by veteran South African anti-Apartheid activists such as Bishop Desmond Tutu, and by international legal experts under commission from the United Nations (Falk and Tilley 2017).

Soyilwella is a strong, slow, gentle, harmonically rich South African anti-colonial song in the Zulu language. The received words translate as 'We will struggle, we will keep struggling, until Africa is free' although the feeling of the music expresses a depth of commitment to long term struggle without translation. Nevertheless, San Ghanny changed 'Africa' to 'Palestine' and also sang it in Arabic translation. A second South African song in the repertoire is Freedom is Coming, a rousing, energetic mobilising song, usually involving dancing, which San Ghanny sung in alternating English and Arabic verses exclaiming 'Freedom is coming, Justice is coming, Power is coming'.

Both of these songs are a core part of the concert repertoire in Scotland, which provides the important connection with the South African solidarity movement. For many in Scotland, the anti-Apartheid movement was a significant tangible form of international solidarity which forms a symbolic reference point both for its popularity amongst key sections of civil society (eg students, artists, third world development groups, trade unions, churches) as well as for its success in contributing to the dismantling of Apartheid (Nelson Mandela was honoured with the Freedom of the City of Glasgow in 1981, at a time when the UK government regarded him as a terrorist). The resonance with South Africa was also central to activist singing in the West Bank.

In 2012 San Ghanny sang these songs when participating in one of the regular Friday demonstrations at Nabi Saleh, with a strong, ongoing tradition of resistance, often focused 
around a water well, occupied by the illegal Israeli colony of Halamish. The Israeli military defends the settlers' confiscation of the well and denies the Nabi Saleh residents access, and has been subjecting the village to sustained persecution for a number of years. The demonstrations involve a march of men, women and children from the Mosque towards the well, following midday prayers, usually accompanied by international and Israeli solidarity activists and press. The march is routinely stopped, a considerable distance away from the well, by the Israeli army's use, variously, of tear gas, 'skunk' (foul smelling chemical water canon), sound bombs and rubbercoated bullets, and occasionally live ammunition. The protestors are unarmed, although some of the young men use slingshots to project small stones (and occasionally return tear gas canisters) to defend the village. On this occasion, San Ghanny were asked to lead the march, and sang whilst marching towards the army lines as far as was regarded as safe, and then sat in the road singing whilst the occupying soldiers watched through their visors. The violence was delayed a little by the use of song, although tear gas started to be launched at Palestinian youths who had spread out on the nearby hills, leading to slingshot response. The singing continued until tear gas escalated and a volume of skunk was fired towards the choir and other demonstrators.

The context of singing these songs in direct nonviolent defiance, and with Palestinians confronting the occupying army, can be contrasted with the same songs sung in a concert in the village of Qusra, in Nablus Governorate, as part of the Nablus Festival. Qusra is divided between Area $\mathrm{B}$ and $\mathrm{C}$ under the Oslo Accords (ie under Israeli security control but with administration in Area B devolved to the Palestine Authority), and around half of the homes in the village have demolition orders, including the village hall, funded by German aid. The village is surrounded by illegal Israeli colonies from which settlers harass and threaten the residents. Despite this, everyday social and economic life of farming, nurturing, studying and hospitality continues. San Ghanny had been asked to sing in Qusra as our first concert in 2017. Unlike Nabi Saleh, there are few international visitors to Qusra and the only faces unlike theirs that the people regularly see are Israeli soldiers and the violent, ideological Israeli settlers. In the village hall San Ghanny sang to and with men, women and children of all ages, including the poignant Soyilwella and energetic, hopeful Freedom is Coming amongst clapping, stamping and cheering, after which we shared laughter, drinks and sweets as if among old friends.

A third example is again from 2012, when San Ghanny sang next to the separation wall in Bethlehem, surrounded by art of resistance on the unnatural concrete blocks towering to twice 
the height of the Berlin Wall. It was the end of the tour and the choir simply wanted to sing for the sake of it, from emotional exhaustion and as one last act of defiance against the monstrous wall and all that it symbolises. As the choir was singing Freedom is Coming, a young Palestinian man driving past, stopped his car and ran back to join us. "I want to sing with you!" he said, "Hurriya! Hurriya!" (freedom), bouncing on his toes with excitement. So the choir taught him the song and sang and danced the South African Freedom dance with him, believing that as Apartheid ended in South Africa, so it is possible for the occupation of Palestine to end.

\section{Palestinian songs}

In addition to music from South Africa, San Ghanny learned from the tradition of Palestinian songs of resistance. Prior to the first visit, the choir had learned an arrangement (by Scottish musician and friend Jane Schonveld) of the well known traditional Arabic song of exile Hadee Ya Bahar which facilitated the opportunity to sing with Palestinians in a range of contexts. Yet more powerful was being taught songs by Palestinian activists. During the same demonstration at Nabi Saleh, described above, after everyone had retreated in the face of skunk water cannon, we were led back towards the stolen well, defying the occupying soldiers, in a re-formed demonstration by some inspiring young women. As we progressed towards the line of soldiers, the young women taught us a song widely popular in Palestine: Biktub ismak ya b'ladi.

\section{I will write your name o my country, above the sun that never sets. \\ Not my children nor my wealth, above your love there is no love.}

'B'ladi' is sometimes translated as country, sometimes nation, but its meaning is much more than that. It really means land as in earth, as in the earth we dig and grow trees and crops on, the rock the wells are dug down into and the sea and the sky as well. It means all of these things as they relate to us, as we exist in relationship to the earth, the land that we live upon. All of these things are bound together through our shared cultural expression as well, so a simple song reflects a complex expression of a people's right to exist. For Palestinians, occupied now by Israel, but occupied by the British and Ottoman empires before them, asserting this right to exist as Palestinians is crucial. And song and dance are fundamental expressions of that identity.

The song is also popular with children and the choir was able to join in the song in 2012 with a kindergarten in Hebron (who also sung to us about their fathers, brothers and 
uncles incarcerated in Israeli prisons) and in 2017 with slightly older children at the New Askar refugee camp in Nablus (who recited a song about Israeli repression against their loved ones). A common misinformation promoted by Zionists is that Palestinians teach their children to hate. Whilst the Israeli occupation could not do more to encourage hatred, the Palestinian teachers and youth workers worked to encourage dignified resistance, not hate. As one of the activists working with the children put it:

"They're trying to break something in the children. We are trying to build something up, to give them hope and make them strong. To help them seek peace rather than revenge."

The choir also sings Biktub ismak ya b'ladi in Scotland, where its easy chorus makes joining in easy, and its bouncy Arabic rhythm provides an opportunity to learn the most basic steps of a Palestinian Dabka dance. At a demonstration outside the Scottish Parliament it also provided the ideal opportunity for Palestinian exiles living in Scotland to join with the choir in a song with which they are familiar.

\section{Civil Rights movement}

The black civil rights movement in the USA confronted segregation, racism and violent brutality comparable to that experienced by Palestinians, and also nourished a strong song tradition of resistance, many of them rooted in the devotional music of the African American Churches. Perhaps the best known is We Shall Overcome, which San Ghanny sang in English and Arabic (sawfa nantaser). The simple and widely known lyrics makes the song well suited to encouraging people to join in: both in Palestine, where, in the right context - a demonstration or an act of resistance - the shared, hope-filled 'We' emphasises solidarity; and in Scotland, which helps to galvanise solidarity action such as boycotts and demonstrations.

One context in which We shall overcome was particularly relevant was planting olive saplings on the land of an activist in A' Twani in the Hebron hills. A' Twani is in Area C, prevented from development by the Israeli military and surrounded by colonies of particularly virulent ideological settlers, who regularly seize land, uproot olive trees, poison livestock and harass children on their way to school. San Ghanny was asked by our hosts to help to plant olive trees along a fence which had been erected by settlers to exclude Palestinians and their international supporters from land that had recently been confiscated by settlers. After some thirty minutes of tree planting, armed Israeli military personnel approached the group and presented a sheet of 
paper in Hebrew, a military order requiring us to leave the area. When attempts at negotiation were clearly not going to succeed - and potentially cause a backlash against our hosts - singing became the most valuable option available to us whilst we quickly watered and heeled in the remaining half-planted trees. A couple of songs extended the time available - an act of defiance which nonetheless avoided provoking an active confrontation - finishing with We shall overcome in English and Arabic. In a tense and potentially volatile situation, the song conceded the immediate retreat whilst asserting in a non-aggressive format, our solidarity and conviction that the colonisers will not win (at least some of the soldiers will have understood English or Arabic).

\section{Peace movement}

Several of our songs were gleaned from the peace movement. One such song is Peace Salaam Shalom, a chorus made up of a simple round, with a solo plaintively calling out the names of places experiencing conflict (in San Ghanny's case, places in Palestine). When the choir learned the song there was much discussion about its suitability. The chorus (the word 'peace' in English, Arabic and Hebrew) and naming the places of conflict, could easily be misinterpreted as promoting any of the various 'peace' initiatives which Israeli state and civil society advocate in order to 'normalise' the occupation and legitimise the colonial relationship between Israelis and Palestinians. It risks, in the wrong context, depoliticising the occupation and treating the settlercolonisation project as a 'conflict between two peoples' - a trope widely promoted by Zionists. However, there was one particular occasion where this song was absolutely appropriate.

In Al Ma'sara in 2012 San Ghanny met Soliman at a demonstration against land confiscation. The soldiers blocked the path of the demonstration but were not violent, and activists were able to speak with the soldiers face to face. Some of the popular resistance committee took the opportunity to speak with the soldiers, mostly conscripts, young men and women in their late teens or early twenties, in English which at least some of them understood. Soliman told the soldiers, "Our lands are occupied, but your minds are occupied as well. Think about what you are being asked to do." The actions tried reaching out to their humanity whilst confronting them to see the reality they are part of. Some of the soldiers were visibly surprised by this nonviolent challenge to their narrative.

As the demonstration ended, the Palestinian villagers turned to walk back to their homes. They had been denied access to their land, but had nonetheless asserted their rights and made clear that 
they would keep on seeking justice. San Ghanny sang Peace Salaam Shalom. There were again expressions of surprise in the faces of some of the soldiers as they recognised their own language. Slowly, they dispersed, some of them becoming uncomfortable with the gentle intensity of our message of peace. The song was echoing the earlier words of challenge and giving space for reflection.

Another song from the peace movement is The Boundary Song, which has its roots in the peace camp at the gates to the Molesworth military establishment in Cambridgeshire, England.

They say this land is out of bounds

our lives and our futures are out of our hands

this land is not yours to put boundaries around

we'll grow, we'll get louder, our voices resound

In Palestine, the incessant confiscation of land by Israel, and the creation of ever more complex boundaries and means of policing them, gives this song new significance. Indeed, San Ghanny has sung it in front of the segregation wall and other 'boundaries' between colonisers and Palestinians. In 2012, the choir sang this song in the village of Jayyous, from which land has been progressively confiscated by Israel to build the segregation wall and extend settler colonies. A farmer took the choir to an area of his land where olive trees had been destroyed by the Israeli military, and signs erected in red Hebrew letters, presumably saying 'no entry'. He was engaged in a legal battle to prevent the confiscation of this land. As he invited us to ignore the 'no entry' signs and walk across his land, The Boundary Song was the most appropriate song that was sung.

\section{Back in Scotland}

In the ongoing work in Scotland, the group has identified three (overlapping) areas for intervention by solidarity singing. The first is as a motivating and conscientising experience for the committed activist, linking the work of activists (some of whom have never visited Palestine, or not for a long time) with the ongoing struggles of Palestinians and how solidarity work is valued. This 'message' can be communicated verbally, but to convey the 'structure of feeling' of connection with Palestinians struggling in their everyday and extraordinary ways, song enters a different level of solidarity. The second level is the sympathetic supporter, who might be galvanised into action. In this case, the emotional connection with song and creativity becomes a 
link between the feelings of commitment and the objective practice of action, whether implementing a boycott or joining in campaigns or travelling to Palestine in solidarity. The third level is to reach new audiences for awareness of Palestinian struggle, largely amongst those with an interest in song. In this case, the connection is most clearly through music and the politics emerges indirectly through emotional engagement.

\section{Conclusions}

Implicit in the Zionist project is manufacturing a 'Land without a People' by eliminating the Palestinian People and erasing their culture and collective memory as well as expelling the population. Retaining and celebrating the Palestinian culture defeats that Zionist project, despite its superiority in military might and international recognition. Linking that culture to the Palestinian past, maintains a collective sense of Palestinian resistance, a 'community of struggle'. Connecting it through song to struggles throughout the world helps to strengthen the movement against the settler-colonisation of Palestine, to understand it as part of a global struggle against colonialism, dispossession, apartheid and ethnic cleansing and serves to boost the international movement of solidarity through boycott, divestment and sanctions against Israel. In this sense, solidarity singing helps to generate a structure of feeling, in which embryonic possibilities of a decolonised future, in Palestine and globally, are 'felt' before they are materialised. Songs of protest, in Palestine and internationally, negate the Zionist project of ethnic cleansing. San Ghanny therefore positions itself as a community of political singers, and also of solidarity activists in the nonviolent tradition of the Palestinian popular resistance.

\section{References}

al-Butmeh, Abeer, al-Shalalfeh, Zayneb and Zwahre, Mahmoud, with Scandrett, Eurig 2019

'The environment as a site of struggle against settler-colonisation in Palestine.' In Anne Harley and Eurig Scandrett (eds) Environmental Justice, Popular Struggle and Community Development. Bristol: Policy Press 
al-Shalalfeh, Zayneb, Napier, Fiona. \& Scandrett, Eurig 2018 Water Nakba in Palestine: Sustainable Development Goal 6 versus Israeli hydro-hegemony, Local Environment, Vol 23. No. $1117-124$

Barghouti, Omar. 2011. BDS: Boycott, Divestment, Sanctions: The Global Struggle for Palestinian Rights. Chicago IL: Haymarket Books.

BBC 2011 'Protests disrupt Proms concert by Israel Philharmonic' BBC online 2 September 2011 http://www.bbc.co.uk/news/uk-14756736 [accessed 7/12/17]

BDS Movement nd Boycott, Divestment Sanctions Movement website https://bdsmovement.net/ [accessed 23 November 2019]

Brown, Mark 2014 'Israeli theatre group has performances cancelled at Edinburgh Fringe' The Guardian 1 August 2014 https://www.theguardian.com/stage/2014/aug/01/israeli-theatre-groupperformances-cancelled-edinburgh-fringe-gaza [accessed 7/12/17]

Darweish, Marwan and Rigby, Andrew 2015 Popular Protest in Palestine: The Uncertain Future of Unarmed Resistance. London: Pluto

Eyerman, Ron and Jamison, Andrew 1998 Music and Social Movements: Mobilising Traditions in the Twentieth Century Cambridge: Cambridge University Press

Falk, Richard. and Tilley, Virginia 2017 Israeli Practices towards the Palestinian People and the Question of Apartheid. Palestine and the Israeli Occupation, Issue No. 1. Beirut: United Nations Economic and Social Commission for Western Asia (ESCWA)

Gaztambide-Fernández, Rubén 2012 'Decolonization and the pedagogy of solidarity’ Decolonization: Indigeneity, Education \& Society Vol. 1, No. 1, 2012, pp. 41-67

Hall, Duncan 2001 'A pleasant change from politics' Music and the British labour movement between the wars. Cheltenham: New Clarion Press

MacColl, Ewan. 1954 Personal choice by Ewan MacColl of Scottish folksongs and ballads, London; Workers' Music Association

Masalha, Nur. 2012 The Palestine Nakba: Decolonising history, narrating the subaltern, reclaiming memory. London: Zed 
McDonald, David A. 2013 My Voice Is My Weapon: Music, Nationalism, and the Poetics of Palestinian Resistance Durham: Duke University Press

Munro, Ailie, and MacLeod, Morag 1996 The democratic muse: folk music revival in Scotland Aberdeen: Scottish Cultural Press

Qumsiyeh, Mazin B. 2010 Popular Resistance in Palestine: A History of Hope and

Empowerment London: Pluto

San Ghanny 20171001 Olive Trees: Tales of Resistance. Edinburgh: Seeds of Hope

Samuel, Raphael., MacColl, Ewan and Cosgrove, Stuart 1985 Theatres of the Left 1880-1935:

Workers' Theatre Movements in Britain and America. (History Workshop Series.) Boston:

Routledge \& Kegan Paul.

Soliman, Mahmoud 2019 Mobilisation and Demobilisation of the Palestinian Society Towards Popular Resistance from 2004-2014, PhD thesis; University of Coventry

Williams, Raymond. 1977 Marxism and Literature. Oxford: Oxford University Press 